\title{
The Growth of Arctic Marine Phytoplankton in Frobisher Bay
}

\author{
STEPHEN I.C. HSIAO'
}

\begin{abstract}
During the summers of 1977 and 1978, populations of phytoplankton collected in Frobisher Bay at depths of 0,5,10, 15, 20 and $25 \mathrm{~m}$ were enclosed in dialysis bags and incubated in situ at the depths from which they were collected. The greatest growth rate of the populations occurred at $10 \mathrm{~m}$ in July-August 1977 and at $5 \mathrm{~m}$ in late August-early September 1978 . Exponential growth rates and generation times of dominant species of phytoplankton are tabulated. Growth rates ranged from 0.06 to 1.12 division day $^{-1}$ and generation times varied from 21.4 to $404.7 \mathrm{hr} \cdot$ division $^{-1}$. Light appears to be the major limiting factor for phytoplankton growth in this area; nutrients, temperature and salinity were not limiting in this experiment.
\end{abstract}

Key words: growth rates, generation times, arctic marine phytoplankton, limiting factors

RESUMÉ. Au cours des étés 1977 et 1978, des populations de phytoplancton Échantillonnées à Frobisher Bay à des profondeurs de $0,5,10,15,20$ et $25 \mathrm{~m}$ ont été incubées in situ à l'intérieur de sacs à dialyse aux profondeurs d'échantillonnage ci-mentionnées. Au mois de juillet et d'aôt respectivement c'est à $10 \mathrm{~m}$ de profondeur qu'on a observé la meilleure croissance des populations et à $5 \mathrm{~m}$ au cours de la période allant de la fin aout, début septembre. Les courbes de croissance, les taux de croissance exponentielle de même que les temps de génération des espèces dominantes de phytoplancton sont présentés. Les taux de croissance se sont échelonnés entre 0.06 et 1.12 division-jour ${ }^{-1}$ tandis que les temps de génération ont varie de 21.4 a $404.7 \mathrm{hr} \cdot$ division ${ }^{-1}$. L'ensoleillement semble etre le facteur limitant principal affectant la croissance du phytoplancton dans cette région; la teneur en eléments nutritifs la température et la salinité de l'eau n'ont pas été restrictifs dans cette experience.

Mots clés: les taux de croissance, les temps de génération, phytoplancton marine de l'arctique, des facteurs limitants

Traduit pour le journal par Maurice Guibord.

\section{INTRODUCTION}

The purpose of this investigation was to estimate the growth rates and generation times of the dominant species of phytoplankton by direct observation under near natural summertime conditions and to examine possible factors limiting growth in Frobisher Bay.

Current methods of estimating phytoplankton growth rates in natural assemblages include radiotracer studies (Eppley, 1972; Knoechel and Kalff, 1976; Saino and Hattori, 1977; Redalje and Laws, 1981; Rivkin and Seliger, 1981; Harrison et al., 1982), DNA-binding fluorescent dye technique (Falkowski and Owens, 1982) and dialysis culture (Jensen et al., 1972; Sakshaug and Jensen, 1978). The first method is suitable only for short term (ca $6 \mathrm{hr}$ maximum) estimates of growth because such estimates tend to be biased toward the high side in the long term (Menzel and Dunstan, 1973). It is also limited by the smallest cell sizes that can be isolated (Rivkin and Seliger, 1981) and the size and shape required for autoradiography (Knoechel and Kalff, 1976). The method is further complicated by the difficulty of determining phytoplankton biomass (Eppley, 1981) and by problems associated with unbalanced growth (Eppley, 1981; Rivkin et al., 1982). In the second method there is difficulty in determining the proportion of non-phytoplankton DNA to the total DNA in natural phytoplankton communities. Furthermore, these two methods do not permit accurate estimates of growth rates of individual species of phytoplankton in natural assemblages. In order to overcome the disadvantages of the radiotracer and fluorescent dye techniques in measuring the growth rate under approximate field conditions of light quality and quantity, temperature, salinity and nutrient concentrations, the dialysis culture technique was employed.

\section{MATERIALS AND METHODS}

A semipermeable membrane of dialysis tubing (Spectra/Por 2 , molecular weight cutoff of $12000-14000,7.64 \mathrm{~cm}$ inflated diameter, manufactured by Spectrum Medical Industrial Inc., Los Angeles), which is permeable to dissolved constituents of natural seawater and to the soluble metabolites excreted by organisms, was cut into $30-\mathrm{cm}$ lengths and washed in hot running tap water for 1 hour to remove glycerol. It was then rinsed in three changes of deionized distilled water. The bags were made from this tubing by folding and sealing the bottom $2 \mathrm{~cm}$ with a "Spectra/Por" closure with a locking groove. Each bag was slipped into a 500-ml Wheaton glass serum bottle with perforated walls, allowing the nutrients to diffuse through the membrane and protecting the bags from damage (Fig. 1). The bags were filled with $450 \mathrm{ml}$ of water containing natural populations of phytoplankton collected from the experimental station $\left(63^{\circ} 42.8^{\prime} \mathrm{N}, 68^{\circ} 30.8^{\prime} \mathrm{W}\right)$ in Frobisher Bay (Fig. 2) at depths of $0,5,10,15,20$ and $25 \mathrm{~m}$ and filtered through a $150-\mu \mathrm{m}$ nylon net to remove zooplankton. They were closed with a rubber sleeve stopper fitted with glass tubing inside to allow sampling with a hypodermic syringe without puncturing the bags. The dialysis bags were suspended from a buoy at the depths from which they were collected for 1 to 3 weeks during July-September 1977 and 1978. The bags were kept in motion by strong semidiurnal tides having a maximum vertical range of $11 \mathrm{~m}$ and a mean horizontal speed of about 2 knots (Grainger, 1975). The test phytoplankton inside the bags were thus mixed without the need of a special stirring device. The outside of the dialysis membrane was brushed clean and washed with a jet of water at least once every two days.

For sampling, the bags were placed in a bucket of natural 


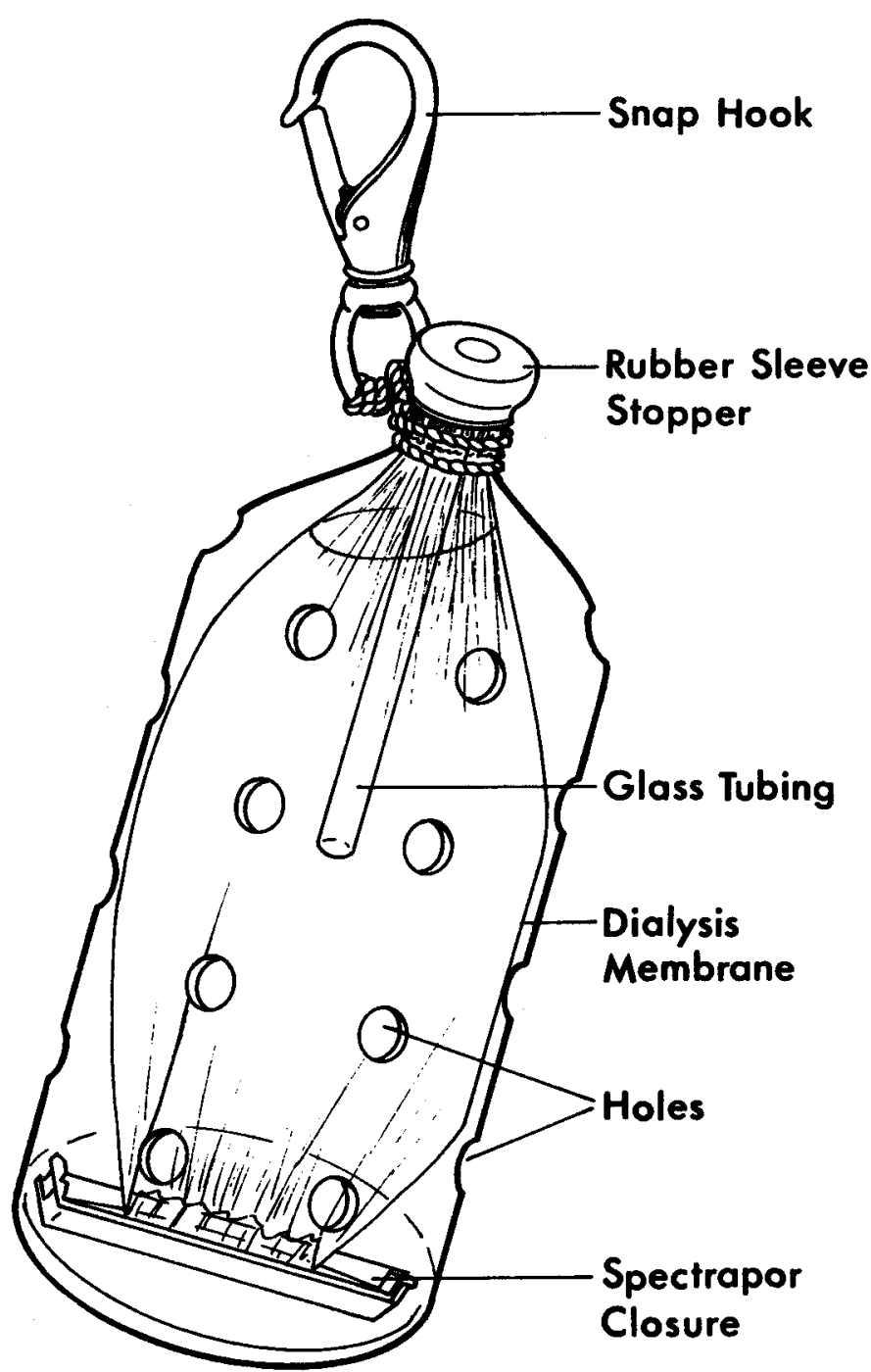

FIG. 1. Dialysis bag used for in situ growth studies of arctic marine phytoplankton.

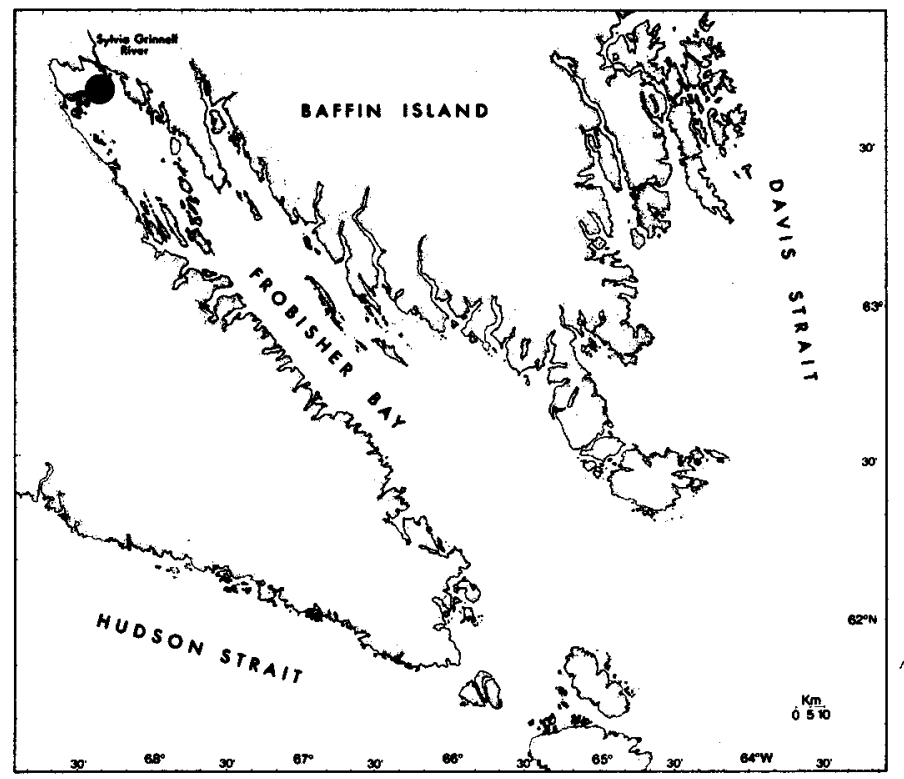

FIG. 2. Location of experimental station in Frobisher Bay. seawater. They were gently agitated to suspend the cells uniformly. Fifty $\mathrm{ml}$ were removed from each of the dialysis bags by means of a syringe inserted through the rubber stopper. Samples were taken at intervals of 2 or 3 days between 1300 and 1500 hours and preserved with $1.0 \mathrm{ml}$ of concentrated neutral formaldehyde. Later, the preserved phytoplankton species were identified and enumerated.

Exponential growth rates $(k)$ and generation times $(\mathrm{Tg})$ of phytoplankton were determined by counting cells with an inverted microscope and using the formula of Guillard (1973):

$$
\begin{gathered}
\mathrm{k}\left(\text { division } \cdot \text { day }^{-1}\right)=\ln \left(\mathrm{N}_{1} / \mathrm{N}_{0}\right)(1.443 / \mathrm{t})= \\
\log \left(\mathrm{N}_{1} / \mathrm{N}_{0}\right)(3.322 / \mathrm{t})
\end{gathered}
$$

where $N_{1}$ and $N_{0}$ are the cell concentrations at the end and beginning of a period of $t$ days.

$\operatorname{Tg}\left(\right.$ hour $\cdot$ division $\left.^{-1}\right)=24 / \mathrm{k}$

Samples and physical properties of the surrounding seawater were collected and measured whenever the dialysis bags were sampled. Nitrate, phosphate, silicate and chlorophyll $a$ were analyzed with spectrophotometric techniques following the methods of Strickland and Parsons (1972). The values of chlorophyll $a$ were calculated by using the equations of Jeffrey and Humphrey (1975). In situ salinity and temperature were measured with a Whitney model CTU-3 portable conductivity meter $( \pm 0.5 \%)$ and thermometer $\left( \pm 0.05^{\circ} \mathrm{C}\right.$ ) (MontedoroWhitney Corp., San Luis Obispo, California). Solar radiation was measured with an LI-185 Quantum/Radiometer/Photometer equipped with an LI-212S underwater photometric sensor ( $\pm 1 \%$ full scale) (Lambda Instruments Corporation, Lincoln, Nebraska) covered with a tube of dialysis membrane to simulate conditions inside an incubation bag. Irradiance measured in lux was converted to energy units using the relationships (Brock, 1981): $1 \mu \mathrm{Em}^{-2} \mathrm{~s}^{-1} \simeq 51.2 \mathrm{lux}$.

\section{GROWTH RATE (division.day-1)}

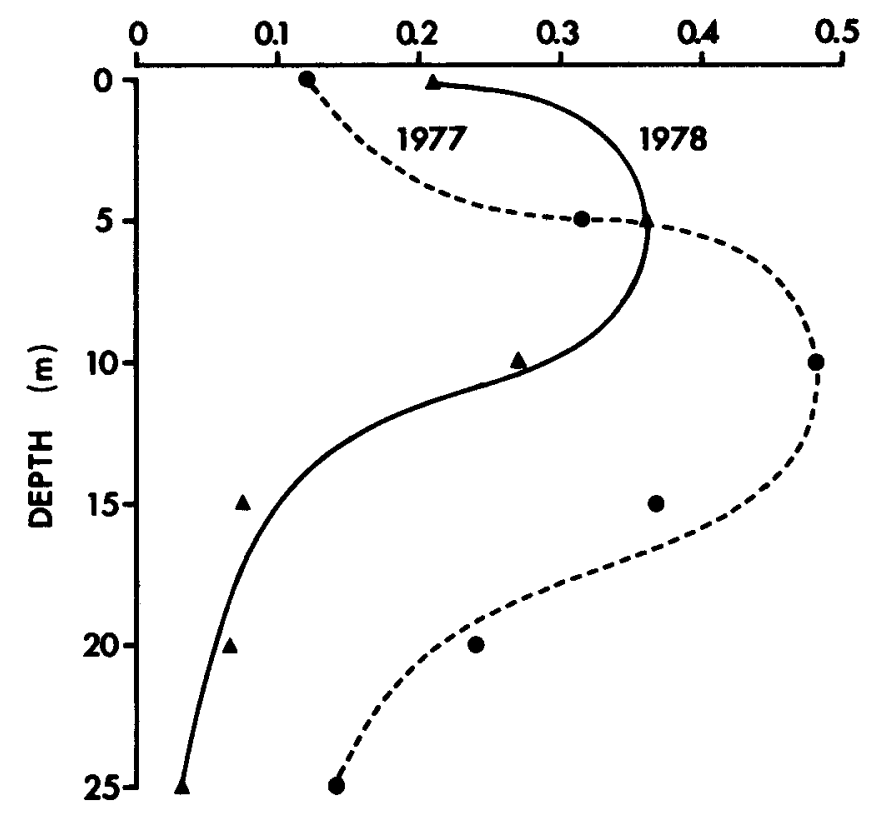

FIG. 3. Depth profile of mean phytoplankton population growth rates in Frobisher Bay. 


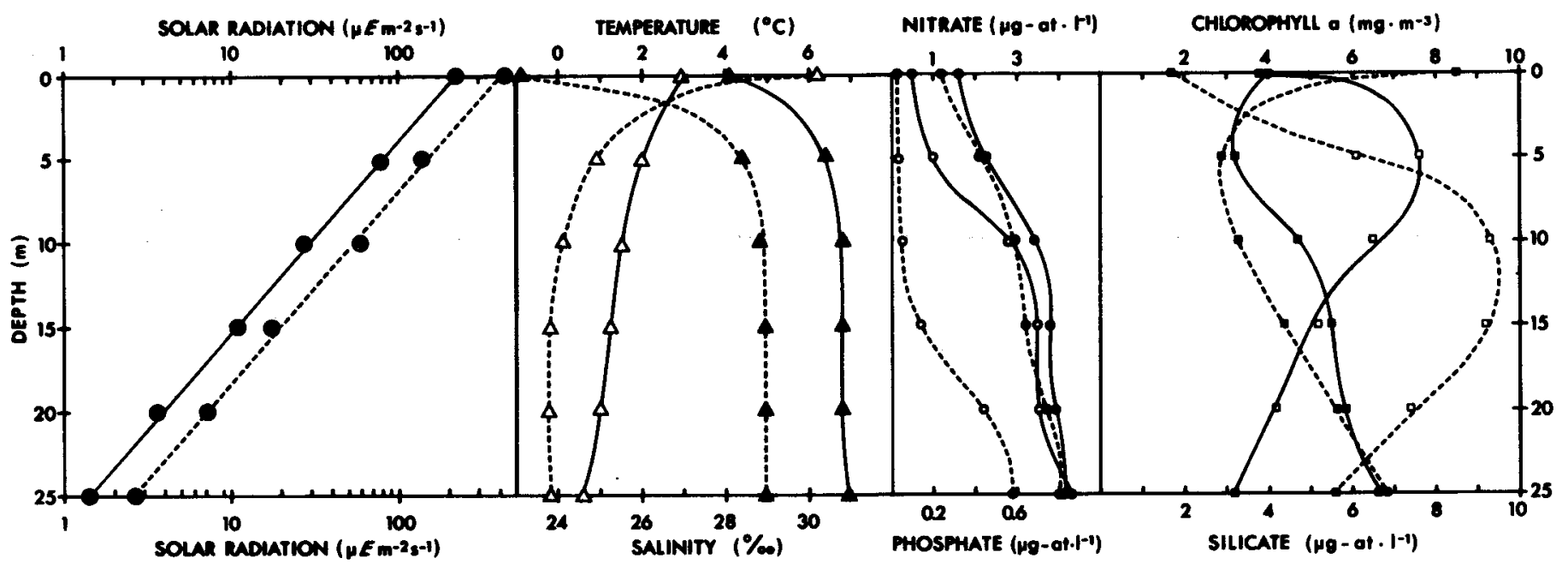

FIG. 4. Profile of mean solar radiation $(O)$, temperature $(\Delta)$, salinity $(\Delta)$, nitrate $(O)$, phosphate $(\bullet)$, silicate $(\square)$ and chlorophyll $a(\square)$ at various depths in Frobisher Bay during July-August $1977(---)$ and August-September $1978(\longrightarrow)$ in situ growth studies.

\section{RESULTS}

Average in situ exponential growth rates of natural populations of arctic marine phytoplankton in Frobisher Bay are shown in Figure 3. Their growth reached a maximum rate of 0.48 division day $^{-1}$ at $10 \mathrm{~m}$ during July-August 1977 and 0.36 division.day $^{-1}$ at $5 \mathrm{~m}$ during August-September 1978, and declined sharply in deeper water. Growth was closely correlated with chlorophyll $a$ and the maximum growth rates coincided with the greatest concentrations (Figs. 4 and 5). Growth rates and generation times of the individual species are listed in Table 1.

The experimental phytoplankton consisted mainly of diatoms, with a great majority being centric species (Table 1). The species of centric diatoms with the highest growth rate and shortest generation time were Chaetoceros diadema (Ehrenberg) Gran, showing 0.96 division.day ${ }^{-1}$ and $25.0 \mathrm{hr}$.division $^{-1}$ at $5 \mathrm{~m}$ during 18-22 July 1977, and Thalassiosira condensata Cleve, with 1.12 division.day ${ }^{-1}$ and $21.4 \mathrm{hr} \cdot$ divi$\operatorname{sion}^{-1}$ at $15 \mathrm{~m}$ during 5-7 August 1978. Chaetoceros compressus Lauder, with 0.07 division.day ${ }^{-1}$ and $338 \mathrm{hr} \cdot \mathrm{divi}$ sion $^{-1}$ at $20 \mathrm{~m}$ during 4-13 August 1977 and Thalassiosira nordenskioeldii Cleve, with 0.06 division.day ${ }^{-1}$ and 404.7 $\mathrm{hr} \cdot$ division $^{-1}$ at $20 \mathrm{~m}$ during 5-10 August 1978, had the lowest growth rates and longest generation times. For pennate diatoms, Nitzschia grunowii Hasle exhibited the highest growth rate and shortest generation time, with 0.31 division $\cdot$ day $^{-1}$ and $78.3 \mathrm{hr} \cdot$ division $^{-1}$ at $10 \mathrm{~m}$ during 4-17 August 1977 and with 0.47 division.day ${ }^{-1}$ and $50.8 \mathrm{hr} \cdot$ division $^{-1}$ in the surface water during 5-16 August 1978. Cylindrotheca closterium (Ehrenberg) Reimann et Lewin, with 0.26 division $\cdot$ day $^{-1}$ and $92.6 \mathrm{hr} \cdot$ division $^{-1}$ at $5 \mathrm{~m}$ during $18-25 \mathrm{July}$ 1977, and Stauroneis quadripedis (Cleve-Euler) Hendey, with 0.12 division $\cdot$ day $^{-1}$ and $193.9 \mathrm{hr} \cdot$ division $^{-1}$ in the surface water during 25 August-6 September 1978, had the lowest growth rates and the longest generation times. The unidentified species of green flagellates had a growth rate as high as 0.90 division $\cdot$ day $^{-1}$ and a relatively short generation time of $26.6 \mathrm{hr} \cdot$ division $^{-1}$ at $15 \mathrm{~m}$ during 25-31 August 1978.

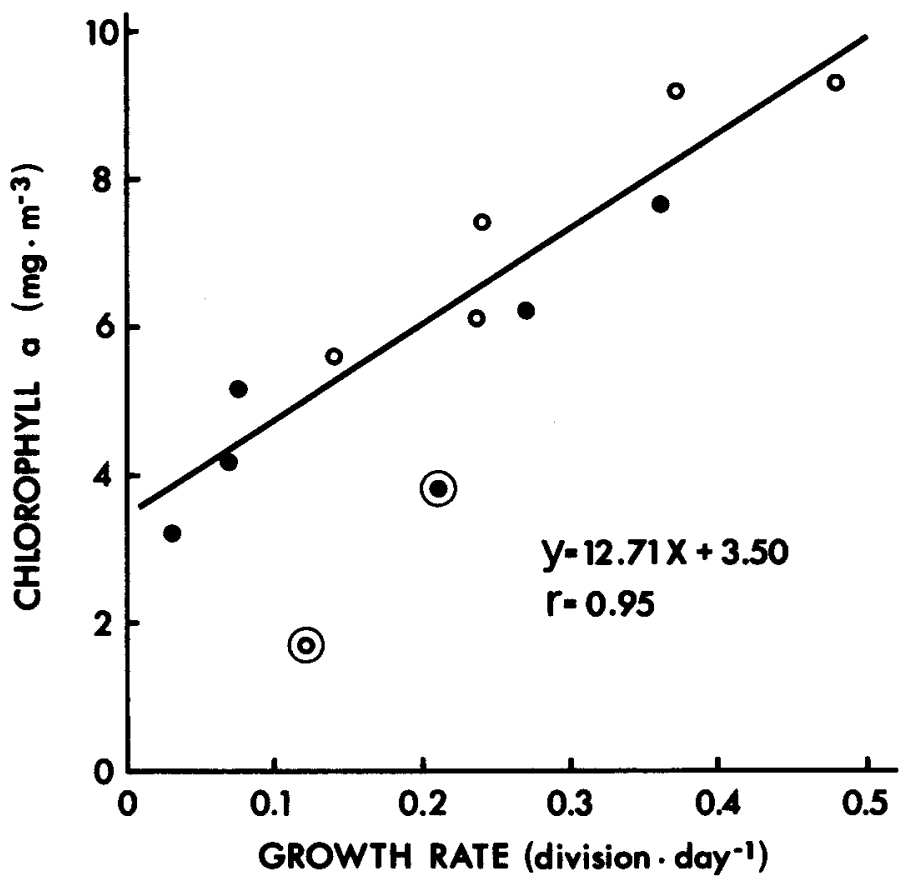

FIG. 5. Relationship between growth rate and chlorophyll $a$ concentration during July-August $1977(O)$ and August-September $1978(\bullet)$ in situ growth studies. ( $r=$ correlation coefficient. Data points marked by a ring are excluded from the regression because of photoinhibition of the surface samples.)

The growth patterns were characterized by the following representative species (Fig. 6): Chaetoceros wighami Brightwell exhibited exponential growth at all depths $(0-25 \mathrm{~m})$ through the period 18-27 July 1977 and at $5 \mathrm{~m}$ during early and mid-August 1978. It exhibited a declining phase mainly at depths greater than $10 \mathrm{~m}$ in August 1977 and in the surface waters and below $10 \mathrm{~m}$ through August and into September 1978. Cylindrotheca closterium (Ehrenberg) Reimann et Lewin occurred only during July 1977 and only a lag phase was observed in the surface water, the exponential phase appeared at 5 and $10 \mathrm{~m}$, and the declining phase showed at depths below $15 \mathrm{~m}$. Nitzschia grunowii Hasle exhibited exponential 
TABLE 1. Exponential growth rates and generation times of arctic marine phytoplankton in Frobisher Bay during the summers of 1977 and 1978

\begin{tabular}{|c|c|c|c|c|c|}
\hline \multirow[b]{2}{*}{ Species } & \multirow{2}{*}{$\begin{array}{c}\text { Depth } \\
\text { (m) }\end{array}$} & \multicolumn{2}{|c|}{ Growth rate (division-day-') } & \multicolumn{2}{|c|}{ Generation time (hr-division-1) } \\
\hline & & July-Aug 1977 & Aug-Sept 1978 & July-Aug 1977 & Aug-Sept 1978 \\
\hline \multicolumn{6}{|l|}{ Centric diatoms } \\
\hline Chaetoceros affinis Lauder & 15 & - & 0.26 & - & 93.7 \\
\hline C. ceratosporum Ostenfeld & $\begin{array}{r}0 \\
5 \\
20\end{array}$ & $\begin{array}{l}- \\
-\end{array}$ & $\begin{array}{l}0.17 \\
0.38 \\
0.53\end{array}$ & $\frac{-}{-}$ & $\begin{array}{r}140.6 \\
62.5 \\
45.7\end{array}$ \\
\hline C. compressus Lauder & $\begin{array}{r}0 \\
5 \\
10 \\
15 \\
20 \\
25\end{array}$ & $\begin{array}{c}-\overline{0.16} \\
- \\
0.16 \\
0.07 \\
-\end{array}$ & $\begin{array}{l}0.14 \\
0.15 \\
0.23 \\
0.24 \\
0.21 \\
0.13\end{array}$ & $\begin{array}{c}\overline{1} \\
145.9 \\
- \\
153.1 \\
338.0 \\
-\end{array}$ & $\begin{array}{r}172.8 \\
162.8 \\
105.5 \\
99.8 \\
112.8 \\
181.7\end{array}$ \\
\hline C. convolutus Castracane & $\begin{array}{r}0 \\
5 \\
10 \\
15 \\
20\end{array}$ & $\begin{array}{l}- \\
- \\
- \\
-\end{array}$ & $\begin{array}{l}0.26 \\
0.27 \\
0.34 \\
0.86 \\
1.04\end{array}$ & $\begin{array}{l}- \\
- \\
- \\
-\end{array}$ & $\begin{array}{l}92.5 \\
90.2 \\
71.1 \\
27.8 \\
23.0\end{array}$ \\
\hline C. debile Cleve & $\begin{array}{r}0 \\
5 \\
10 \\
15 \\
20\end{array}$ & $\begin{array}{l}\overline{0.13} \\
0.15 \\
0.15 \\
0.21\end{array}$ & $\begin{array}{l}0.73 \\
0.44 \\
0.34 \\
0.23 \\
0.20\end{array}$ & $\begin{array}{l}\overline{178.1} \\
159.6 \\
155.0 \\
116.3\end{array}$ & $\begin{array}{r}32.9 \\
54.8 \\
71.1 \\
104.6 \\
117.4\end{array}$ \\
\hline C. decipiens Cleve & $\begin{array}{r}0 \\
5 \\
10 \\
15 \\
20\end{array}$ & $\begin{array}{l}- \\
\overline{-} \\
-\end{array}$ & $\begin{array}{l}0.31 \\
0.29 \\
0.29 \\
0.11 \\
0.10\end{array}$ & $\begin{array}{l}- \\
- \\
- \\
-\end{array}$ & $\begin{array}{r}77.5 \\
80.7 \\
82.5 \\
223.7 \\
246.1\end{array}$ \\
\hline C. diadema (Ehrenberg) Gran & $\begin{array}{r}0 \\
5 \\
10 \\
15 \\
20 \\
25\end{array}$ & $\begin{array}{l}0.59 \\
0.96 \\
0.61 \\
0.53 \\
0.50 \\
0.33\end{array}$ & $\begin{array}{l}- \\
- \\
- \\
- \\
-\end{array}$ & $\begin{array}{l}40.7 \\
25.0 \\
39.5 \\
45.2 \\
48.0 \\
72.2\end{array}$ & $\begin{array}{l}- \\
\overline{-} \\
\overline{-} \\
\overline{-}\end{array}$ \\
\hline C. furcellatus J.W. Bailey & $\begin{array}{r}0 \\
5 \\
10 \\
15 \\
20\end{array}$ & $\begin{array}{l}0 . \overline{31} \\
0.30 \\
0.39 \\
0.55\end{array}$ & $\begin{array}{c}0.23 \\
0.51 \\
- \\
- \\
-\end{array}$ & $\begin{array}{l}- \\
77.9 \\
78.8 \\
61.8 \\
43.4\end{array}$ & $\begin{array}{c}106.1 \\
47.0 \\
- \\
- \\
-\end{array}$ \\
\hline C. karianus Grunow & $\begin{array}{r}5 \\
10 \\
15 \\
20\end{array}$ & $\begin{array}{l}0.12 \\
0.31 \\
0.27 \\
0.20\end{array}$ & $\begin{array}{l}- \\
- \\
-\end{array}$ & $\begin{array}{r}207.2 \\
78.6 \\
87.7 \\
121.2\end{array}$ & $\begin{array}{l}- \\
- \\
-\end{array}$ \\
\hline C. laciniosus Schuit & $\begin{array}{r}5 \\
10 \\
15 \\
20\end{array}$ & $\begin{array}{l}0.14 \\
0.18 \\
0.31 \\
0.21\end{array}$ & $\begin{array}{l}- \\
- \\
-\end{array}$ & $\begin{array}{r}167.9 \\
132.4 \\
77.8 \\
114.4\end{array}$ & $\begin{array}{l}\bar{z} \\
\overline{-}\end{array}$ \\
\hline C. socialis Lauder & $\begin{array}{r}0 \\
5 \\
10 \\
15 \\
20 \\
25\end{array}$ & $\begin{array}{l}-\overline{22} \\
0.16 \\
0.07 \\
- \\
-\end{array}$ & $\begin{array}{l}0.54 \\
0.32 \\
0.27 \\
0.12 \\
0.10 \\
0.08\end{array}$ & $\begin{array}{c}-\overline{109.2} \\
150.4 \\
328.8 \\
- \\
-\end{array}$ & $\begin{array}{r}44.4 \\
74.6 \\
89.7 \\
195.9 \\
239.5 \\
290.2\end{array}$ \\
\hline C. wighami Brightwell & $\begin{array}{r}0 \\
5 \\
10 \\
15 \\
20 \\
25\end{array}$ & $\begin{array}{l}0.21 \\
0.52 \\
0.47 \\
0.37 \\
0.35 \\
0.33\end{array}$ & $\begin{array}{c}\overline{0.21} \\
0.47 \\
- \\
- \\
-\end{array}$ & $\begin{array}{r}114.8 \\
46.4 \\
50.6 \\
64.6 \\
67.7 \\
73.1\end{array}$ & $\begin{array}{c}\overline{112.0} \\
51.3 \\
- \\
- \\
-\end{array}$ \\
\hline Thalassiosira condensata Cleve & 15 & - & 1.12 & - & 21.4 \\
\hline T. decipiens (Grunow) E. Jdrgensen & $\mathbf{0}$ & - & 0.33 & - & 72.0 \\
\hline T. gravida Cleve & 10 & - & 0.24 & - & 98.9 \\
\hline T. nordenskioeldii Cleve & $\begin{array}{r}0 \\
5 \\
10 \\
15 \\
20\end{array}$ & $\begin{array}{l}-\overline{0.18} \\
0.31 \\
0.11 \\
0.09\end{array}$ & $\begin{array}{l}0.37 \\
0.19 \\
0.16 \\
0.09 \\
0.06\end{array}$ & $\begin{array}{r}-\overline{134.9} \\
76.9 \\
211.4 \\
273.8\end{array}$ & $\begin{array}{r}64.1 \\
126.2 \\
154.3 \\
260.0 \\
404.7\end{array}$ \\
\hline
\end{tabular}


TABLE 1 (cominued)

\begin{tabular}{|c|c|c|c|c|c|}
\hline \multirow[b]{2}{*}{ Species } & \multirow{2}{*}{$\begin{array}{c}\text { Depth } \\
\text { (m) }\end{array}$} & \multicolumn{2}{|c|}{ Growth rate (division-day ${ }^{-1}$ ) } & \multicolumn{2}{|c|}{ Generation time (hr-division } \\
\hline & & July-Aug 1977 & Aug-Sept 1978 & July-Aug 1977 & Aug-Sept \\
\hline \multicolumn{6}{|l|}{ Pennate diatoms } \\
\hline $\begin{array}{l}\text { Cylindrotheca closterium (E } \\
\text { Reimann et Lewin }\end{array}$ & 5 & 0.26 & - & 92.6 & - \\
\hline Navicula pelagica Cleve & $\begin{array}{r}0 \\
5 \\
10 \\
15\end{array}$ & $\begin{array}{l}0.33 \\
0.26 \\
0.23 \\
0.23\end{array}$ & $\begin{array}{l}- \\
- \\
-\end{array}$ & $\begin{array}{r}73.2 \\
92.2 \\
103.2 \\
106.0\end{array}$ & $\begin{array}{l}- \\
- \\
-\end{array}$ \\
\hline Nitzschia grunowii Hasle & $\begin{array}{r}0 \\
5 \\
10 \\
15\end{array}$ & $\begin{array}{c}- \\
\overline{0.31} \\
-\end{array}$ & $\begin{array}{l}0.47 \\
0.34 \\
0.30 \\
0.14\end{array}$ & $\overline{-}$ & $\begin{array}{r}50.8 \\
70.6 \\
80.8 \\
168.1\end{array}$ \\
\hline $\begin{array}{l}\text { Stauroneis quadripedis (Cle } \\
\text { Hendey }\end{array}$ & $\begin{array}{l}0 \\
5\end{array}$ & - & $\begin{array}{l}0.12 \\
0.24\end{array}$ & - & $\begin{array}{r}193.9 \\
98.2\end{array}$ \\
\hline Unidentified green flagellates & $\begin{array}{l}15 \\
20 \\
25\end{array}$ & $\overline{-}$ & $\begin{array}{l}0.90 \\
0.39 \\
0.29\end{array}$ & $\overline{-}$ & $\begin{array}{l}26.6 \\
61.8 \\
82.3\end{array}$ \\
\hline
\end{tabular}

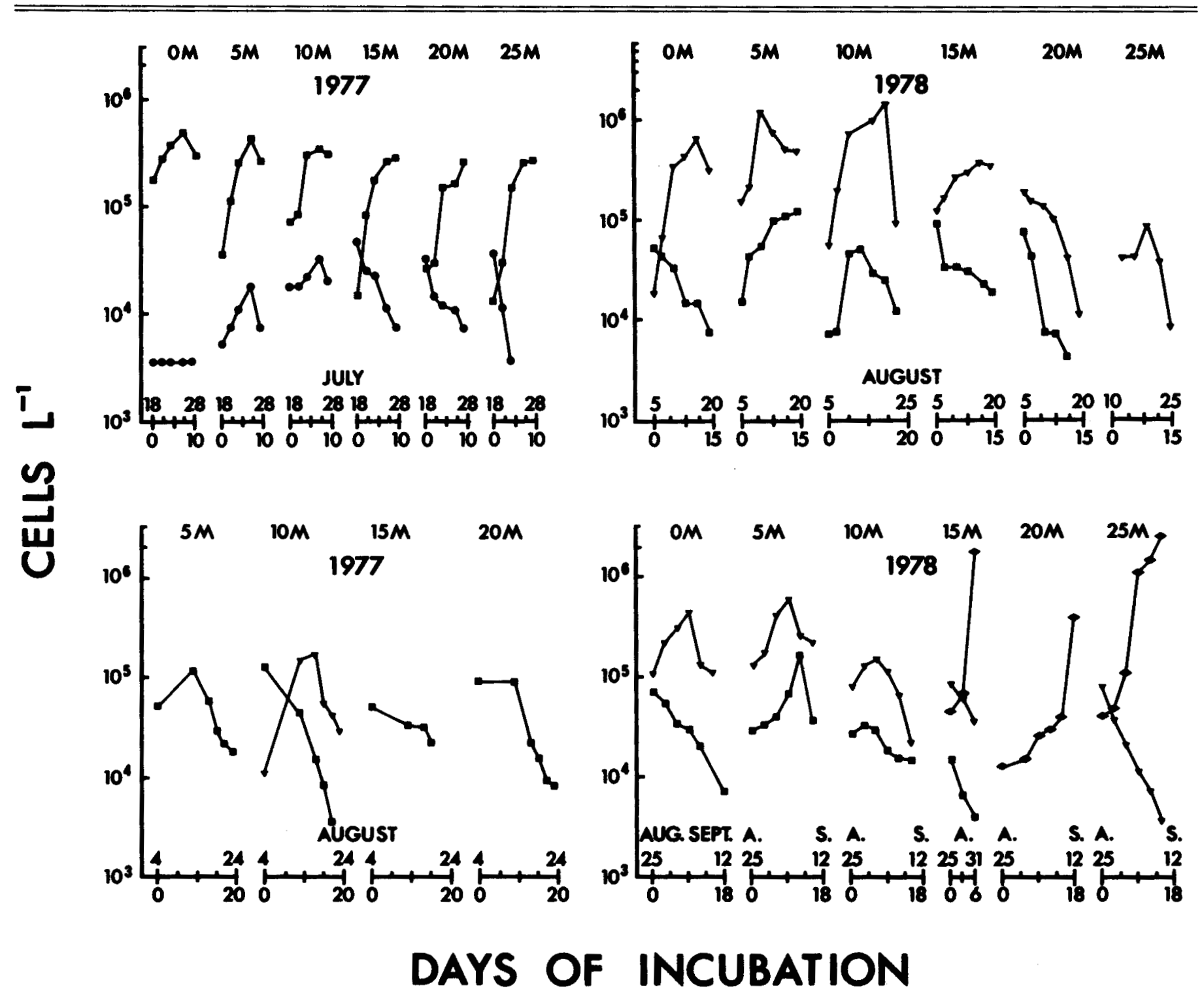

FIG. 6. In situ growth curves of representative species ( Chaetoceros wighami, - Cylindrotheca closterium, $\nabla$ Nitzschia grunowii, - unidentified green flagellates) of arctic marine phytoplankton in Frobisher Bay. 
growth only at $10 \mathrm{~m}$ during early and mid-August 1977 ; this extended to $15 \mathrm{~m}$ at about the same period in 1978 but was restricted to the upper $10 \mathrm{~m}$ during late August and early September 1978. It entered the declining phase at depths lower than $20 \mathrm{~m}$. The unidentified green flagellates grew linearly and occurred only at depths below $15 \mathrm{~m}$ during late August and early September 1978. Dinoflagellates and chrysophytes were occasionally present in low numbers at various depths.

Growth curves, rates and generation times of phytoplankton in Frobisher Bay varied from month to month and from year to year with species, depth, period of incubation, duration of exponential phase and environmental parameters (Figs. 3-8 and Table 1). All the phytoplankton were grown in nearly natural environmental conditions (Fig. 4). Nitrate and phosphate concentrations were generally low near the surface and abundant in the deeper water during all sampling periods. Silicate was continuously supplied from the nearby Sylvia Grinnell River. It was frequently present in excess, though it occurred in lower concentrations at depths of 5 and $10 \mathrm{~m}$ as a result of vigorous growth of diatoms (Figs. 3 and 4). Nitrate $(r=-0.66$, $\mathrm{p}<0.05)$ and silicate $(r=-0.70, \mathrm{p}<0.01)$ are inversely cor-
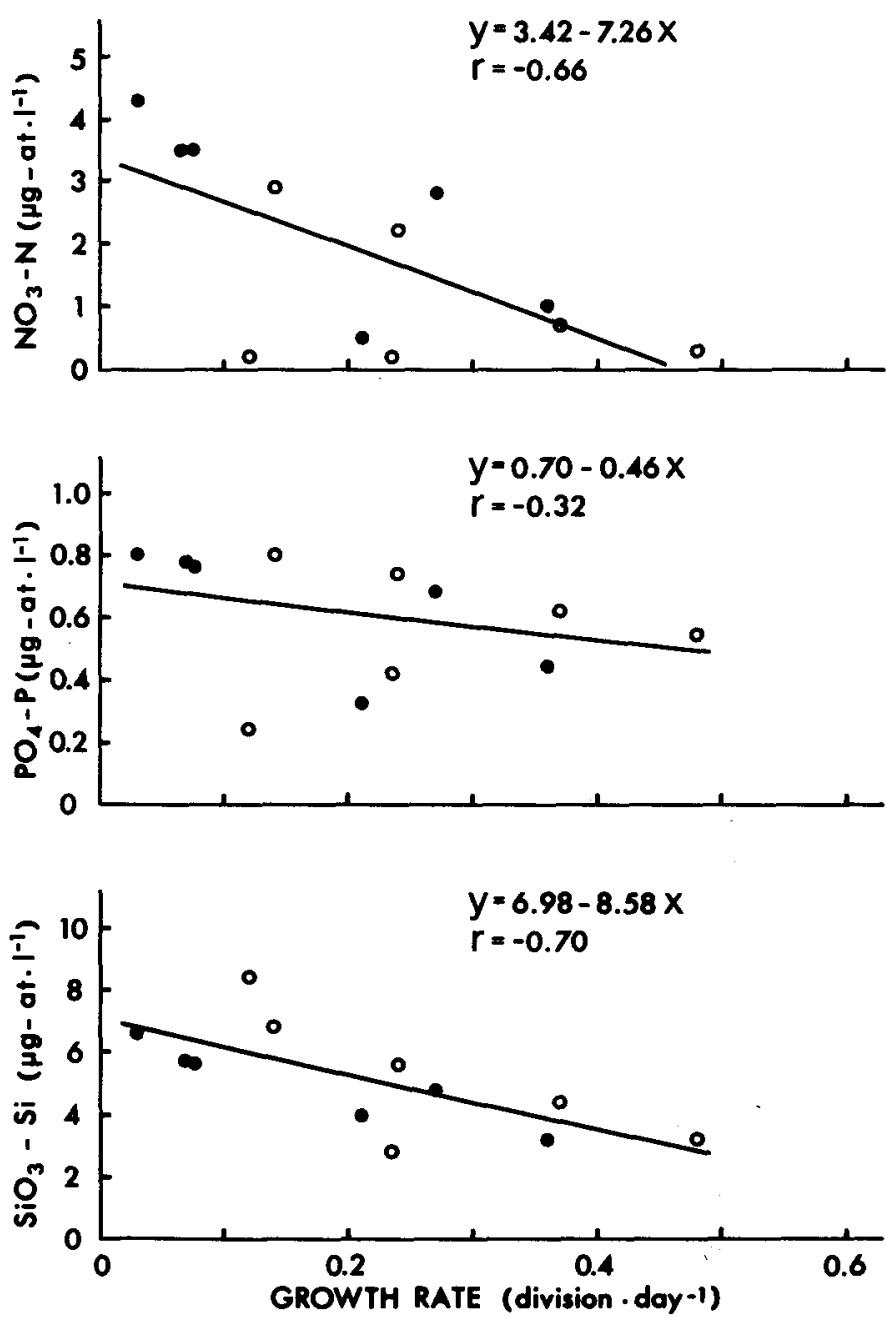

FIG. 7. Relationships between growth rates and nutrients during July-August $1977(O)$ and August-September $1978(\bullet)$ in situ growth studies. ( $\mathrm{r}=$ correlation coefficient.)

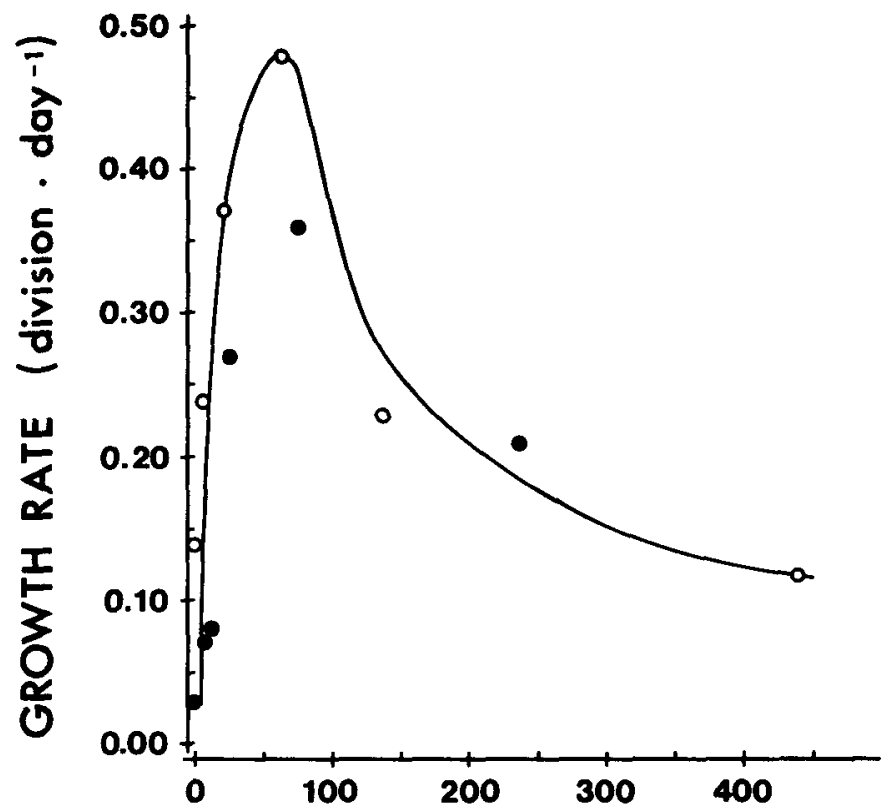

SOLAR RADIATION $\left(\mu E \mathrm{~m}^{-2} \mathrm{~s}^{-1}\right)$

FIG. 8. Relationship between growth rate and solar radiation during JulyAugust $1977(O)$ and August-September $1978(\bullet)$ in situ growth studies.

related with phytoplankton growth (Fig. 7), but phosphate is not $(r=-0.32, p>0.1)$. Salinity was low at the surface, and increased with depth, becoming constant at depths below $10 \mathrm{~m}$ (Fig. 4). There was no evidence of significant effects of salinity (ranging from about 23 to $31 \%$ ) on phytoplankton growth $(r=-0.01, p>0.1)$. Water temperature varied from about $-0.2^{\circ} \mathrm{C}$ at $25 \mathrm{~m}$ to $6.2^{\circ} \mathrm{C}$ at the surface, with most of the sampled depths being between 0 and $2^{\circ} \mathrm{C}$ (Fig. 4). Temperature and phytoplankton growth were not correlated $(r=$ $-0.24, p>0.1$ ). Average light intensity during the study period fluctuated from $435 \mu \mathrm{Em}^{-2} \mathrm{~s}^{-1}$ at the surface to 1.4 $\mu \mathrm{Em}^{-2} \mathrm{~s}^{-1}$ at $25 \mathrm{~m}$. Growth responses of the natural populations of phytoplankton to solar radiation is shown in Figure 8. The growth rates were significantly positively correlated with solar radiation up to $60 \mu \mathrm{Em}^{-2} \mathrm{~s}^{-1}(\mathrm{r}=0.86, \mathrm{p}<0.005)$ and inhibited at higher intensities (Fig. 8).

\section{DISCUSSION}

There is no perfect method for estimating phytoplankton growth rates in the natural environment. The dialysis culture technique suffers from some shortcomings, such as mixing, detrital deposition and epiphytic growth affecting nutrient flux and light penetration through the dialysis membrane (Vargo et al., 1975; Sakshaug and Jensen, 1978). These limitations in the present case are minimal because of the relative lack of epiphytic growth at low arctic temperatures and the strong tidal flushing in Frobisher Bay. Thus, neither the phytoplankton growth on the inside walls of the membrane nor the nutrient concentrations within the bags was measured. 
Growth rates, obtained by the dialysis technique, for individual species from natural phytoplankton assemblages in Frobisher Bay were comparable to the values observed in the surface waters of the Bering Sea and the northern North Pacific Ocean (0.36 to 0.89 doublings. day ${ }^{-1}$ ) (Saino and Hattori, 1977 ) and in Baffin Bay stations (0.01 to 1.03 doublings.day $^{-1}$ ) (Harrison et al., 1982) by radiotracer studies on whole populations of natural phytoplankton. They also fell within the range observed in the euphotic zone of oligotrophic $(<0.5$ doubling $\cdot$ day $\left.^{-1}\right)$ and eutrophic ( $>1.0$ doubling $\cdot$ day $\left.^{-1}\right)$ water in temperate and tropical oceans (Eppley, 1972; Goldman et al., 1979).

Salinity is not a limiting factor for phytoplankton growth in Frobisher Bay. McLachlan (1961) demonstrated that nine different cultures of unicellular marine algae, representing various algal groups, grew well in a wide range of salinity from 2.5 to $35 \%$. Among them, chlorophyte flagellates and dinoflagellates showed a definite salinity optimum for growth, but this was not the case for centric diatoms. Grant and Horner (1976) found that the growth rate of arctic ice diatoms was about the same over a broad range of salinity from 10 to $50 \%$, averaging between 0.6 and 0.8 division $\cdot$ day $^{-1}$. The effects of light intensity, temperature and nutrients on phytoplankton growth rates have been discuissed by Eppley and Strickland (1968). In the arctic marine environment, light and temperature levels are relatively high during summer, but low temperature and extremely short daylight or complete darkness prevail during the winter. The combination of high light intensity and high temperature during summer probably favour the growth of centric diatoms in open waters with relatively low nutrients (Hellebust and Lewin, 1977). This could be the reason that centric diatoms dominated the phytoplankton community (Table 1). The regression analysis of growth vs nutrients yields negative correlation coefficients in the present study. This negative correlation is probably attributable to greater growth rates utilizing more nutrients resulting in lower concentrations in the seawater. This is not the case for phosphate because of more rapid generation (turnover) processes than for other nutrients (Round, 1981). The nutrients are never low enough to limit growth or to be important factors in these experiments. This agrees with the findings of Harrison $e t$ al. (1982), who concluded that nutrient availability in Baffin Bay was not an important limiting factor, and suggested that light and temperature might be more important than nutrient limitation in controlling eastern arctic phytoplankton production. Eppley (1972) and Goldman and Carpenter (1974) found that growth rate is species specific as well as a function of temperature and light.

The present study shows that the regression of phytoplankton growth on light intensity is linear up to $60 \mu \mathrm{Em}^{-2} \mathrm{~s}^{-1}(\mathrm{r}=$ $0.86, \mathrm{p}<0.01$ ) at $10 \mathrm{~m}$ and $0.2^{\circ} \mathrm{C}$. This light saturation for growth is apparently 5 times lower than maximum photosynthesis (ca $322.0 \mu \mathrm{Em}^{-2} \mathrm{~s}^{-1}$ ) found by Platt et al. (1980) in Scott Inlet in the Canadian eastern Arctic. This confirms the findings of Hellebust (1970) that the light requirement for maximum growth is considerably lower than that necessary for maximum photosynthesis in short-term experiments. At this light saturation, the growth reaches a maximum (Fig. 8) and the phytoplankton contain the highest concentration of chlorophyll $a$ (Fig. 4). Thus, chlorophyll $a$ is positively correlated with light intensity $(r=0.70, p<0.05)$ and with growth $(r=$ $0.95, \mathrm{p}<0.001)$. At higher intensities $\left(77-435 \mu \mathrm{EM}^{-2} \mathrm{~s}^{-1}\right)$, usually accompanied by higher temperatures in the surface water, both chlorophyll $a(r=-0.98, p<0.05)$ and growth $(r=-0.92, p>0.05)$ are strongly negatively correlated. During the study period, the highest surface temperature was $6.2^{\circ} \mathrm{C}$ and growth was negatively correlated with surface temperature $(r=-0.73, p>0.1)$. The growth declines as a result of over-saturation by light in Frobisher Bay, possibly because of photoinhibition of photosynthesis (Platt et al., 1980; Gallegos et al., 1983). Recently, Platt et al. (1980, 1982) introduced an empirical equation to describe phytoplankton photosynthesis as a continuous function of available light from the initial linear response through the photoinhibited range in natural assemblages of marine phytoplankton. The major factor that may be expected to control phytoplankton growth in Frobisher Bay during summer in the surface water is light intensity. For the waters between $5 \mathrm{~m}$ and $25 \mathrm{~m}$ under conditions of sufficient nutrients and normal temperature and salinity, light is the prime factor $(r=0.86, p<0.01)$ influencing growth. For the waters at depth below $25 \mathrm{~m}$, in the lower part of the euphotic zone where nutrients are plentiful and temperature remains constant, the availability of light becomes more critical. It seems reasonable to conclude that this may be the ultimate limiting factor for arctic phytoplankton growth in Frobisher Bay. It also reveals that light is more important than other parameters, particularly immediately after the sunless winter months of ice cover.

\section{ACKNOWLEDGEMENTS}

I wish to express my sincere gratitude to D. Lussier-Brown, D. Michaud, J.R. Brown and P. Kinnis for carrying out the field work relating to this study; to G. Vickers and D. Lussier-Brown for identifying and enumerating the the phytoplankton; to J. Fife and Dr. J.A. Percy for assistance with data analyses; and to Dr. E.H. Grainger for his helpful criticism of the manuscript.

\section{REFERENCES}

BROCK, T.D. 1981. Calculating solar radiation for ecological studies. Ecological Modelling 14:1-19.

EPPLEY, R.W. 1972. Temperature and phytoplankton growth in the sea. Fishery Bulletin, 70(4): 1063-1085.

1981. Relations between nutrient assimilation and growth in phytoplankton with a brief review of estimates of growth rate in the ocean. Canadian Bulletin of Fisheries and Aquatic Sciences 210:251-263.

and STRICKLAND, J.D.H. 1968. Kinetics of marine phytoplankton growth. In: Droop, M.R., and Wood, E.J.F. (eds.). Advances in Microbiology of the Sea. Vol. 1. London: Academic Press. 23-62.

FALKOWSKI, P.G., and OWENS, T.G. 1982. A technique for estimating phytoplankton division rates by using DNA-binding fluorescent dye. Limnology and Oceanography 27(4):776-782.

GALLEGOS, C.L., PLATT, T., HARRISON, W.G., and IRWIN, B. 1983. Photosynthetic parameters of arctic marine phytoplankton: vertical variations and time scales of adaptation. Limnology and Oceanography 28:698-708. 
GOLDMAN, J.C., and CARPENTER, E.J. 1974. A kinetic approach to the effect of temperature on algal growth. Limnology and Oceanography 19:756-766.

GOLDMAN, J.C., McCARTHY, J.J., and PEAVEY, D.G. 1979. Growth rate influence on the chemical composition of phytoplankton in oceanic waters. Nature 279:210-215.

GRAINGER, E.H. 1975. A marine biology study in Frobisher Bay, Arctic Canada. In: Cameron, T.W.M., and Billingsley, L.W. (eds.). Energy flow: its Biological Dimensions. Ottawa: The Royal Society of Canada. 261-266.

GRANT, W.S., and HORNER, R.A. 1976. Growth responses to salinity variation in four arctic ice diatoms. Journal of Phycology 12:180-185.

GUILLARD, R.R.L. 1973. Division rates. In: Stein, J.R. (ed.). Handbook of Phycological Methods: Culture Methods and Growth Measurements. London: Cambridge University Press. 289-320.

HARRISON, W.G., PLATT, T., and IRWIN, B. 1982. Primary production and nutrient assimilation by natural phytoplankton populations of the eastern Canadian Arctic. Canadian Journal of Fisheries and Aquatic Sciences 39(2):335-345.

HELLEBUST, J.A. 1970. Light: plants. In: Kinne, O. (ed.). Marine Ecology. Vol. 1. Environmental factors. Part 1. London: WileyInterscience. 125-158.

and LEWIN, J. 1977. Heterotrophic nutrition. In: Werner, D. (ed.). The Biology of Diatoms. Oxford: Blackwell Scientific Publications. 169-197.

JEFFREY, S.W., and HUMPHREY, G.F. 1975. New spectrophotometric equations for determining chlorophylls $a, b, c_{1}$ and $c_{2}$ in higher plants, algae and natural phytoplankton. Biochemie und Physiologie de Ptlanzen (BPP) 167:191-194.

JENSEN, A., RYSTAD, B., and SKOGLUND, L. 1972. The use of dialysis culture in phytoplankton studies. Journal of Experimental Marine Biology and Ecology 8:241-248.

KNOECHEL, R., and KLAFF, J. 1976. The applicability of grain density autoradiography to quantitative determination of algal species production: a critique. Limnology and Oceanography 21:583-590.

McLACHLAN, J. 1961. The effect of salinity on growth and chlorophyll content in representative classes of unicellular marine algae. Canadian Journal of Microbiology 7:399-406.

MENZEL, D.W., and DUNSTAN, W.M. 1973. Growth measurements by analysis of carbon. In: Stein, J.R. (ed.). Handbook of Phycological Methods: culture methods \& growth measurements. London: Cambridge University Press. 313-320.

PLATT, T., GALLEGOS, C.L., and HARRISON, W.G. 1980. Photoinhibition of photosynthesis in natural assemblages of marine phytoplankton. Journal of Marine Research 38:687-701.

PLATT, T., HARRISON, W.G., IRWIN, B., HORNE, E.P., and GALLEGOS, C.L. 1982. Photosynthesis and photoadaptation of marine phytoplankton in the arctic. Deep-Sea Research 29:1159-1170.

REDALJE, D.G., and LAWS, E.A. 1981. A new method for estimating phytoplankton growth rates and carbon biomass. Marine Biology 62:73-79.

RIVKIN, R.B., and SELIGER, H.H. 1981. Liquid scintillation counting for ${ }^{14} \mathrm{C}$ uptake of single algal cells isolated from natural assemblages. Limnology and Oceanography 26:780-785.

RIVKIN, R.B., VOYTEK, M.A., and SELIGER, H.H. 1982. Phytoplankton division rates in light-limited environment: two adaptations. Science 215:1123-1125.

ROUND, F.E. 1981. The ecology of algae. London: Cambridge University Press. 653 p.

SAINO, T., and HATTORI, A. 1977. Estimate of the growth rate of phytoplankton in the surface waters of the Bering Sea and the northern North Pacific. Marine Science Communication 3(1):1-19.

SAKSHAUG, E., and JENSEN, A. 1978. The use of cage cultures in studies of the biochemistry and ecology of marine phytoplankton. Annual Review of Oceanography and Marine Biology 16:81-106.

STRICKLAND, J.D.H., and PARSONS, T.R. 1972. A practical handbook of seawater analysis. Fisheries Research Board of Canada Bulletin 167:1-310.

VARGO, G.A., HARGRAVES, P.E., and JOHNSON, P. 1975. Scanning electron microscopy of dialysis tubes incubated in flowing seawater. Marine Biology 31:113-120. 